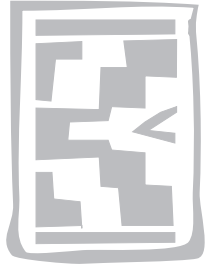

\title{
The effects of low levels of dietary trace minerals on the plasma levels, faecal excretion, health and performance of pigs in a hot African climate
}

\author{
M.H. BOMA and G. BILKEI* \\ Veterinary Consulting, Bahnhofstrasse 42, CH - 8600 Dübendorf, Switzerland
}

\begin{abstract}
BOMA, M.H. \& BILKEI, G. 2009. The effects of low levels of dietary trace minerals on the plasma levels, faecal excretion, health and performance of pigs in a hot African climate. Onderstepoort Journal of Veterinary Research, 76:291-297

The present study was performed in order to evaluate the effects of lower than usual industry levels of dietary trace minerals on plasma levels, faecal excretion, performance, mortality and morbidity in growing-finishing pigs in a hot African climate.
\end{abstract}

Group 1 ( $n=100$ pigs) received a diet with common industry levels of trace minerals.

Group 2 ( $n=100$ pigs) received reduced dietary trace mineral levels but were fed the same basic diet as Group 1.

Mortality, morbidity, pig performance and carcass measurements were evaluated.

Two pigs in Group 1 and three pigs in Group 2 died. Thirteen pigs in Group 1 and 27 pigs in Group 2 were medically treated $(P<0.05)$.

Carcass masses, back fat depth, loin depth, and lean percent were not significantly different between the groups. However, the carcasses when evaluated revealed a non-significant higher back fat thickness, lower loin eye area and percentage of fat-free lean in barrows compared to gilts within each group.

Despite lower initial masses, pigs fed diets containing industry levels of trace minerals were heavier $(P<0.05)$ and had a higher $(P<0.05)$ than average daily gains compared to those that received a diet containing lower levels of trace minerals.

Faecal zinc excretion was significantly lower $(P<0.05)$ in pigs fed with lower dietary zinc levels. Copper, manganese and iron excretion were not affected $(P>0.05)$ by the dietary levels of these trace minerals.

Plasma trace mineral concentrations were not affected by the dietary treatment.

Keywords: Climate, mortality, morbidity, performance, pigs, trace element

\section{INTRODUCTION}

Higher than usual levels of zinc and copper recommended for the pig production industry by the $\mathrm{Na}-$ tional Research Council, USA (1998) are often added for disease prophylaxis or growth promotion in

* Author to whom correspondence is to be directed: E-mail: bilkei.consulting@gmx.net

Accepted for publication 19 February 2009-Editor the diets of nursery and growing-finishing pigs in Central and Eastern Europe (Bilkei, Biro, Bölcskei, Clavadetscher, Orban, \& Waller 1995). Klasing (2001) suggested that in order to optimize immune function and health, trace mineral requirements may be greater than requirements for growth performance. However, it has also been demonstrated that reducing dietary trace mineral levels does not affect pigs growth performance (Creech, Spears, Flowers, Hill, Lloyd, Armstrong \& Engle 2004). Bilkei et al. 
(1995) suggested, that reduced levels of excreted trace minerals may diminish the negative effects of the environment. The same authors found that in many Eastern European pig units, higher dietary levels than suggested by the National Research Council (1998) regarding zinc (150-3000 ppm), copper (17-80 ppm), manganese (50-136 ppm) and iron (350-601 ppm), were fed.

Accumulation of zinc and copper in soils are of concern in areas where manure from swine facilities is applied to them (Jongbloed \& Lenis 1993). It has been shown that when lower than the National Research Council (1998) standard of dietary zinc and copper were fed, there was reduced excretion in the faeces of gilts (Creech et al. 2004). In a study (Creech et al. 2004), the dietary levels of zinc (from 100 to $25 \mathrm{ppm}$ ) and copper (from 15 to $5 \mathrm{ppm}$ ) were reduced in grower-finisher pigs diets. In addition, the authors (Creech et al. 2004) reduced the levels of iron (from 100 to $25 \mathrm{ppm}$ ) and manganese (from 40 to $10 \mathrm{ppm}$ ) of the diet in order to minimize the antagonistic effects of these trace minerals on the absorption of zinc and copper, without affecting the pigs' growth performance. Similarly, Van Huegten, O'Quinn, Funderburke, Flowers \& Spears (2004) found that reduced levels of trace minerals in growing-finishing pigs diet resulted in lower faecal excretion, without any negative effects on the performance of the pigs. In contrast to this, and according to our (unpublished) experiences in a hot African climate, lower than suggested (National Research Council, 1998) trace element levels decrease fattening performance.

The authors cited (Bilkei et al. 1995; Klasing 2001; Creech et al. 2004; Huegten et al. 2004) did not evaluate morbidity and mortality of their trial animals and did not take climatic factors into consideration.

The objective of the present study was to evaluate the effects of lower than recommended levels of dietary trace minerals on mortality and morbidity, plasma levels, faecal excretion, and performance in growing-finishing pigs in a hot African climate.

\section{MATERIALS AND METHODS}

The study was performed in a large Kenyan breeding and growing-finishing unit from April 2007 to April 2008.

In the trial, the herd suffered from a high rate of infections caused by gastrointestinal and respiratory pathogens. Pretrial necropsies revealed a low rate of infection with Lawsonia intracellularis, Brachyspira hyodysenteriae and beta-haemolytic Escherichia coli, while ELISA tests using a Tween-20 detergentextracted antigen have shown that mycoplasmal infections are present in the herd and an ELISA for the detection bacterial antigen against Actinobacillus pleuropneumoniae serotypes 1, 2, 5, 7 and 9 has given positive results. No toxigenic Pasteurella multocida strain has been found in this unit, and swine influenza virus immunfluorescent antibody tests were negative. The unit was free from of Salmonella choleraesuis.

The study was performed in two groups of pigs which were randomly selected from a computergenerated list within blocks of animals of similar mass (Table 1). Equal numbers of gilts and barrows were represented in each group. The animals were ear-tagged with consecutive numbers at the beginning of the trial.

Group 1 ( $n=100$ pigs, 50 gilts, 50 barrows) received a diet containing higher levels of dietary trace mineral than is suggested by the National Research Council (1998), in four feeding phases (Table 2).

Group 2 ( $n=100$ pigs, 50 gilts, 50 barrows) received a diet containing reduced levels of trace mineral but were fed the same basic diet as those in Group 1.

The trial animals were moved from the nursery "flatdeck" barns at the age of 7-8 weeks to the growingfinishing barn and were housed in pens each of which contained ten animals $\left(0.97 \mathrm{~m}^{2}\right.$ per pig, partly slotted floors [1/3 of the pen]). The two rooms of pens in the barn were separated from each other by a central aisle. The pigs were therefore raised under the same management and environmental con-

TABLE 1 Growth performance of growing-finishing pigs in a hot African climate. Group 1 received trace mineral levels suggested by the NRC, USA (1998), while Group 2 received reduced levels

\begin{tabular}{|l|c|c|l|l|}
\hline Pig data & Group 1 & Group 2 & SEM & $P$ value \\
\hline Initial mass $(\mathrm{kg})$ & 19.20 & 21.10 & 0.88 & $>0.05$ \\
Final mass $(\mathrm{kg})$ & 118.10 & 114.10 & 0.36 & $<0.05$ \\
Mortality \% & 2.00 & 3.00 & & $<0.05$ \\
Morbidity \% & 13.00 & 27.00 & & $<0.05$ \\
Average daily gain $(\mathrm{kg})$ & 0.78 & 0.69 & 0.01 & \\
\hline
\end{tabular}


ditions. The pigs had ad libitum access to water, were, apart from the trace element compounds, fed ad libitum with an identical commercial diet from the same feeding mill in each phase (Table 2) and were raised in "all-in/all-out" management system. No prophylactic antimicrobial drugs were used.

Initial and slaughter masses for each group were recorded.

\section{Mortality and morbidity data}

Mortality data included any death regardless of its cause. Morbidity data included treatments for diarrhoea, skin infections, respiratory diseases and diseases of joints. Mortality and morbidity rates were recorded and evaluated as a percentage of the group, concerned.

\section{Pig performance and carcass measurements}

The total number of days in the trial was calculated from the start and end dates of each group. Average daily gain (ADG) was calculated from the total mass at placement, total mass at marketing, and the total number of days to marketing.

Feed disappearance was calculated from the total feed delivered to each group, corrected for feed remaining at the end of the trial, the number of pigs in each group, and the total number of days in the trial.

Carcass measurements of each individual pig in each group were collected at slaughter, and included gender, hot carcass mass, back fat and loin deposit (by using an optical probe), and percent lean body.

\section{Laboratory procedure}

Feed samples were collected and fresh faecal samples (30 pigs per group [3 pigs per pen]) were obtained randomly at the same time upon defaecation from three pigs in each pen during the second week in each feeding phase (Table 2). Samples were dried in an oven at $60^{\circ} \mathrm{C}$, and then ground through

TABLE 2 Experimental diets of the pigs. Group 1 received the trace mineral levels suggested by the NRC, USA (1998), while Group 2 received reduced levels

Diet formula for both groups of pigs weighing from $19-115 \mathrm{~kg}$

\begin{tabular}{|l|l|l|l|l|l|}
\hline Phases & Mass $\mathbf{( k g )}$ & Protein (\%) & Lysine (\%) & Calcium (\%) & Phosphorus (\%) \\
\hline 1 & $19-25$ & $17-18$ & 1.1 & 0.66 & 0.62 \\
2 & $25-40$ & $15-16$ & 0.9 & 0.66 & 0.67 \\
3 & $41-60$ & $13-14$ & 0.8 & 0.65 & 0.55 \\
4 & $61-115$ & $13-14$ & 0,8 & 0.64 & 0.54 \\
\hline
\end{tabular}

Amino acid patterns for the pigs in relation to lysine for both groups

\begin{tabular}{|l|c|c|}
\hline Amino acid & $\mathbf{1 9 - 6 0} \mathbf{~ k g}$ & $>\mathbf{6 0} \mathbf{~ k g}$ \\
\hline Lysine & 100 & 100 \\
Methionine + cystine & 65 & 65 \\
Threonine & 67 & 70 \\
Tryptophan & 18 & 19 \\
Arginine & 30 & 18 \\
Valine & 68 & 68 \\
Isoleucine & 60 & 60 \\
Leucine & 100 & 100 \\
Phenylalanine + tryptophan & 100 & 100 \\
Histidine & 32 & 32 \\
\hline
\end{tabular}

Analysed trace mineral composition of the diets for both groups

\begin{tabular}{|l|l|l|l|l|l|l|l|l|}
\hline \multirow{2}{*}{$\begin{array}{l}\text { Trace mineral } \\
\text { (ppm) }\end{array}$} & \multicolumn{2}{|l|}{ Phase 1 } & \multicolumn{2}{l|}{ Phase 2 } & \multicolumn{2}{l|}{ Phase 3 } & \multicolumn{2}{l|}{ Phase 4 } \\
\cline { 2 - 9 } & $\begin{array}{l}\text { Group 1: } \\
\text { normal }\end{array}$ & $\begin{array}{l}\text { Group 2: } \\
\text { reduced }\end{array}$ & $\begin{array}{l}\text { Group 1: } \\
\text { normal }\end{array}$ & $\begin{array}{l}\text { Group 2: } \\
\text { reduced }\end{array}$ & $\begin{array}{l}\text { Group 1: } \\
\text { normal }\end{array}$ & $\begin{array}{l}\text { Group 2: } \\
\text { reduced }\end{array}$ & $\begin{array}{l}\text { Group 1: } \\
\text { normal }\end{array}$ & $\begin{array}{l}\text { Group 2: } \\
\text { reduced }\end{array}$ \\
\hline Zinc & 177 & 78 & 159 & 71 & 148 & 70 & 130 & 79 \\
Copper & 18 & 11 & 22 & 9 & 18 & 11 & 19 & 11 \\
Manganese & 69 & 60 & 68 & 53 & 48 & 37 & 57 & 41 \\
Iron & 516 & 380 & 487 & 365 & 362 & 271 & 295 & 251 \\
\hline
\end{tabular}


TABLE 3 Analysed trace mineral composition of the faeces (dry matter basis) of the pigs. Group 1 received trace mineral levels suggested by the NRC, USA (1998), while Group 2 received reduced levels

\begin{tabular}{|c|c|c|c|c|c|c|c|c|}
\hline \multirow{3}{*}{$\begin{array}{l}\text { Trace mineral } \\
\text { ppm }\end{array}$} & \multicolumn{2}{|l|}{ Phase 1} & \multicolumn{2}{|l|}{ Phase 2} & \multicolumn{2}{|l|}{ Phase 3} & \multicolumn{2}{|l|}{ Phase 4} \\
\hline & $\begin{array}{l}\text { Group 1: } \\
\text { normal }\end{array}$ & $\begin{array}{l}\text { Group 2: } \\
\text { reduced }\end{array}$ & $\begin{array}{l}\text { Group 1: } \\
\text { normal }\end{array}$ & $\begin{array}{l}\text { Group 2: } \\
\text { reduced }\end{array}$ & $\begin{array}{l}\text { Group 1: } \\
\text { normal }\end{array}$ & $\begin{array}{l}\text { Group 2: } \\
\text { reduced }\end{array}$ & $\begin{array}{l}\text { Group 1: } \\
\text { normal }\end{array}$ & $\begin{array}{l}\text { Group 2: } \\
\text { reduced }\end{array}$ \\
\hline & \multicolumn{8}{|l|}{$\mathrm{ppm}_{ \pm} \mathrm{SEM}$} \\
\hline $\begin{array}{l}\text { Zinc } \\
\text { Copper } \\
\text { Manganese } \\
\text { Iron }\end{array}$ & $\begin{array}{c}1187 \pm 108 \mathbf{a} \\
131 \pm 15 \mathbf{a} \\
459 \pm 41 \mathbf{a} \\
2511 \pm 169 a\end{array}$ & $\begin{array}{r}367 \pm 78 \mathbf{b} \\
95 \pm 12 \mathbf{a} \\
245 \pm 42 \mathbf{a} \\
1381 \pm 141 \mathbf{a}\end{array}$ & $\begin{array}{c}1149 \pm 11 \mathbf{a} \\
142 \pm 16 \mathbf{a} \\
428 \pm 38 \mathbf{a} \\
2580 \pm 131 \mathbf{a}\end{array}$ & $\begin{array}{c}397 \pm 80 \mathbf{b} \\
91 \pm 11 \mathbf{a} \\
223 \pm 29 \mathbf{a} \\
2333 \pm 145 \mathbf{a}\end{array}$ & $\begin{array}{c}1141 \pm 116 \mathbf{a} \\
125 \pm 14 \mathbf{a} \\
419 \pm 42 \mathbf{a} \\
2261 \pm 129 \mathbf{a}\end{array}$ & $\begin{array}{c}371 \pm 78 \mathbf{b} \\
81 \pm 13 \mathbf{a} \\
231 \pm 45 \mathbf{a} \\
2273 \pm 131 \mathbf{a}\end{array}$ & $\begin{array}{c}1031 \pm 102 a \\
118 \pm 13 \mathbf{a} \\
461 \pm 46 \mathbf{a} \\
2291 \pm 148 \mathbf{a}\end{array}$ & $\begin{array}{r}71 \pm 75 \mathbf{b} \\
81 \pm 12 \mathbf{a} \\
231 \pm 32 \mathbf{a} \\
2233 \pm 121 \mathbf{a}\end{array}$ \\
\hline
\end{tabular}

a, $\mathbf{b}$ in a row: the difference is significant, $P<0.05$

TABLE 4 Analysed trace mineral composition of the plasma of pigs. Group 1 received trace mineral levels as suggested by the NRC, USA (1998), while Group 2 received reduced levels

\begin{tabular}{|c|c|c|c|c|c|c|c|c|}
\hline \multirow{3}{*}{$\begin{array}{l}\text { Trace mineral } \\
\text { ppm }\end{array}$} & \multicolumn{2}{|l|}{ Phase 1} & \multicolumn{2}{|l|}{ Phase 2} & \multicolumn{2}{|l|}{ Phase 3} & \multicolumn{2}{|l|}{ Phase 4} \\
\hline & $\begin{array}{l}\text { Group 1: } \\
\text { normal }\end{array}$ & $\begin{array}{l}\text { Group 2: } \\
\text { reduced }\end{array}$ & $\begin{array}{l}\text { Group 1: } \\
\text { normal }\end{array}$ & $\begin{array}{l}\text { Group 2: } \\
\text { reduced }\end{array}$ & $\begin{array}{l}\text { Group 1: } \\
\text { normal }\end{array}$ & $\begin{array}{l}\text { Group 2: } \\
\text { reduced }\end{array}$ & $\begin{array}{l}\text { Group 1: } \\
\text { normal }\end{array}$ & $\begin{array}{l}\text { Group 2: } \\
\text { reduced }\end{array}$ \\
\hline & \multicolumn{8}{|l|}{$\mathrm{mg} / \ell_{ \pm} \mathrm{SEM}$} \\
\hline $\begin{array}{l}\text { Zinc } \\
\text { Copper } \\
\text { Iron }\end{array}$ & $\begin{array}{l}0.71 \pm 0.08 \mathbf{a} \\
2.23 \pm 0.5 \mathbf{a} \\
1.31 \pm 0.6 \mathbf{a}\end{array}$ & $\begin{array}{l}0.72 \pm 0.07 \mathbf{a} \\
1.84 \pm 0.4 \mathbf{a} \\
1.39 \pm 0.3 \mathbf{a}\end{array}$ & $\begin{array}{l}0.69 \pm 0.03 \mathbf{a} \\
1.95 \pm 0.5 \mathbf{a} \\
1.26 \pm 0.3 \mathbf{a}\end{array}$ & $\begin{array}{l}0.77 \pm 0.02 \mathbf{a} \\
1.99 \pm 0.2 \mathbf{a} \\
1.30 \pm 0.5 \mathbf{a}\end{array}$ & $\begin{array}{l}0.74 \pm 0.06 \mathbf{a} \\
1.98 \pm 0.4 \mathbf{a} \\
1.29 \pm 0.2 \mathbf{a}\end{array}$ & $\begin{array}{l}0.78 \pm 0.06 \mathbf{a} \\
1.21 \pm 0.4 \mathbf{a} \\
1.28 \pm 10.3 \mathbf{a}\end{array}$ & $\begin{array}{l}0.81 \pm 0.07 \mathbf{a} \\
2.08 \pm 0.4 \mathbf{a} \\
1.29 \pm 0.3 \mathbf{a}\end{array}$ & $\begin{array}{l}0.76 \pm 0.07 a \\
2.11 \pm 0.2 \mathrm{a} \\
1.28 \pm 0.4 \mathrm{a}\end{array}$ \\
\hline
\end{tabular}


a 1-mm screen prior to trace mineral analysis. When the faecal samples were collected, blood samples were obtained from the same pigs from the anterior vena cava using Vacutainer heparinized tubes (Becton Dickinson, Zagreb, Croatia).

Feed and faecal samples were digested by wet ashing with nitric acid and hydrogen peroxide using a microwave digestion system (Model MDS-81D; CEM Corp. Matthews, NC, USA) as described by Gengelbach, Ward \& Spears (1994). Ashed samples were subsequently analysed for zinc, copper, iron and manganese using an atomic absorption spectrophotometer (model AA-6701F; Shimadzu, Kyoto, Japan). Plasma samples were diluted in nitric acid, then analysed for the same elements by atomic absorption spectrophotometer. All laboratory procedures of feed, faecal and plasma samples were performed in Veterinary Investigation Centre in Zagreb, Croatia.

\section{Statistical analyses}

Data were analysed by analysis of variance as a randomized complete block design using the General Linear Model (GLM) of Statistical Analytical System (SAS 1999, SAS Institute Inc. Cary, NC. USA). The model for morbidity, mortality, growth performance, trace mineral excretion data, and plasma trace mineral concentrations included blocks and trace mineral inclusion levels (high or low), using a group as the experimental unit. The model for carcass data included block, trace mineral supplementation level and gender, and the interaction of block and trace mineral supplementation level. The latter was used as an error term to test the effect of trace mineral supplementation on carcass characteristics. The experimental unit for this analysis was the individual pig. In addition, carcass data were analysed using carcass mass as a co-variate to evaluate carcass characteristics at a common carcass mass.

\section{RESULTS}

Two pigs (1 gilt and 1 barrow) died in Group 1 (that had received higher than recommended levels of the trace elements), and three pigs (one gilt and two barrows) died in Group 2 (that received lower than recommended levels of trace minerals). Owing to the low number of death no statistical analyses were performed. Thirteen pigs (six gilts and seven barrows) had to be medically treated in Group 1, and 27 pigs (11 gilts and 16 barrows) in Group $2(P<$ 0.05).
Carcass masses (Group 1: $86.9 \pm 2.1 \mathrm{~kg}$; Group 2: $86.7 \pm 2.5 \mathrm{~kg}, P>0.05$ ) back fat depth (Group 1: $18.9 \pm 2.2 \mathrm{~mm}$; Group 2: $18.7 \pm 2.3 \mathrm{~mm}, P>0.05$ $\mathrm{mm}$ ), loin depth (Group 1: $58.9 \pm 2.9 \mathrm{~mm}$; Group 2: $59.3 \pm 4.2 \mathrm{~mm}, P>0.05 \mathrm{~mm}$ ), and lean percent (Group 1: $54.1 \pm 3.2 \%$; Group 2: $53.7 \pm 3.1 \%, P>$ $0.05 \mathrm{~kg}$ ) were not significantly different between the groups. The carcasses revealed a non-significant higher back fat thickness (gilts: $19.7 \pm 2.1 \mathrm{~mm}$; barrows: $17.6 \pm 2.3 \mathrm{~mm}, P>0.05 \mathrm{~mm}$ ), lower loin eye area (gilts: $60.2 \pm 3.0 \mathrm{~mm}$; barrows: $59.1 \pm 3.1 \mathrm{~mm}, P$ $>0.05 \mathrm{~mm}$ ), and percent fat-free lean (gilts: $55.0 \pm$ $3.1 \%$; barrows: $53.1 \pm 3.0 \%, P>0.05 \mathrm{~kg}$ ) in barrows compared to gilts within each group.

Despite lower initial masses (19.2 kg vs. $21.1 \mathrm{~kg}$, Table 1), pigs fed diets containing higher than usual "industry" levels of trace minerals were heavier $(P<$ $0.05)$ and had a higher $(P<0.05)$ ADG compared to the pigs that received the diet containing lower levels of trace minerals (Table 1).

Faecal excretion of zinc was significantly lower $(P<$ $0.05)$ in pigs fed with lower dietary zinc levels compared with the pigs that received higher zinc levels. Copper, manganese and iron excretion were not significantly affected $(P>0.05)$ by their dietary levels (Table 3).

Plasma trace mineral concentrations were not affected by the dietary treatment (Table 4).

\section{DISCUSSION}

In the present trial the gilt and barrow ratio were identical in the groups. Therefore, the differences in performance observed in the present study cannot be attributed to differences in gender distribution.

During the trial, many of the pigs in the herd suffered from gastrointestinal and respiratory infections, and nearly $30 \%$ of the pigs receiving lower dietary trace mineral levels had to be treated. Thus, it seems reasonable to assume that lower dietary trace mineral levels might have contributed to their higher disease prevalence and lower performance. Klasing (2001) suggested that in order to optimize immune function and health, trace mineral requirements may be greater than requirements for growth performance. As the only difference between the groups was the dietary trace mineral concentration, it is reasonable to conclude, that the lower trace mineral content of the diet in Group 2 might have contributed to lower resistance against the present pathogens in this unit, causing higher morbidity 
compared to the pigs having received higher dietary trace mineral levels.

Carcass characteristics did not differ significantly between the groups. These findings confirm the findings of Heugten et al. 2004. Similarly, Paboeuf, Nys \& Corlouer (2000) reported no differences in carcass characteristics for barrows and gilts fed diets with reduced levels of copper or zinc, or both in either the finisher period or the entire grower-finisher period. Consistent with the findings of Goodwin \& Burrough (1995), in the present study the carcasses revealed a higher backfat thickness, and a lower loin eye area and percentage of fat-free lean in barrows as compared to gilts.

In contrast to the findings of Paboeuf et al. (2000), Creech et al. (2004) and Heugten et al. (2004) in the present study, pigs fed diets containing higher levels of trace minerals were heavier $(P<0.05)$ and had a higher $(P<0.05)$ ADG compared to the pigs that had received a diet containing lower levels of trace minerals.

Zinc is excreted via the faeces (Weigand \& Kirchgessner 1980) while most of the copper is excreted in the bile with only minute amounts being excreted in the urine (Mahoney, Bush, Gubler, Moretz, Cartwright \& Wintrobe 1955). According to Underwood (1977), the absorption and excretion of copper and zinc are strictly regulated through homeostatic control mechanisms, and when these trace minerals are consumed in quantities exceeding the requirements, the excess is excreted. Consistent with the present results, Creech et al. (2004) suggested that zinc and copper excretion could be reduced by up to $40 \%$ by reducing their supplementation to levels recommended by the National Research Council, USA (1998). Paboeuf et al. (2000) reported that excretion of copper was lowered by $76 \%$ and that of zinc by $14 \%$, when pigs were fed diets containing reduced levels of copper (from $92 \mathrm{ppm}$ to 15-18 ppm) and zinc (from 125 to $90 \mathrm{ppm}$ ). In the present study the reduction of these trace elements was different from that of the cited authors as our copper levels were not as high as those in the study of Paboeuf et al. (2000) and our zinc levels were generally higher in the Group 1 and lower in the Group 2 as compared to those used by those authors. The higher reduction of zinc excretion in the present study, compared to that of obtained by Paboeuf et al. (2000), might be the result of the higher zinc levels fed in our trial. In the study of Heugten et al. 2004, pigs fed with reduced trace mineral levels had lower faecal levels of zinc and tended to be lower for copper, iron and manganese compared to pigs fed with higher levels of these trace minerals. The authors (Heugten et al. 2004) concluded that grower finisher pigs' performance was not negatively affected by lower dietary trace mineral levels.

Jongbloed \& Lenis (1993) calculated that the total excretion of copper could be reduced from $14.4 \mathrm{~g}$ to $4.6 \mathrm{~g}$ per pig in pigs weighing $25-106 \mathrm{~kg}$ by eliminating growth-promoting levels of copper in the starter phase and reducing dietary copper from $35 \mathrm{ppm}$ to $20 \mathrm{ppm}$ in the grower-finisher phase. Total excretion of zinc could be reduced from $21.6 \mathrm{~g}$ to $10.9 \mathrm{~g}$ per pig when dietary zinc was reduced by approximately $50 \%$. Copper and zinc may accumulate in soil and cause leaching and diarrhoea of pigs which have access to such pastures (Jongbloed \& Lenis 1993). Although, in the present study, the dietary manganese content was similar in the different groups, there was (consistent with the findings of Heugten et al. 2004) a tendency for lower faecal manganese excretion. It seems to be reasonable to suggest that the reduction in dietary levels of zinc, copper, and iron might have increased the availability of manganese, resulting in reduced excretion.

In the present trial, plasma concentrations of the trace minerals which were evaluated were within physiological serum concentrations of $0.70 \mathrm{mg} / \mathrm{l}$ to $1.50 \mathrm{mg} / \mathrm{l}, 1.30 \mathrm{mg} / \mathrm{\ell}$ to $3.00 \mathrm{mg} / \mathrm{l}$ copper, $1.00 \mathrm{mg} / \mathrm{\ell}$ to $1.50 \mathrm{mg} / \mathrm{\ell}$ iron (Puls 1994).

\section{CONCLUSION}

It is suggested that in a hot African climate, higher levels of dietary trace minerals in pigs significantly diminish morbidity, increase performance and result in higher average daily mass gains.

\section{REFERENCES}

BILKEI, G., BIRO, O., BÖLCSKEI, A., CLAVADETSCHER, E., ORBAN, P. \& WALLER, C. 1995. Practice related management strategies on post-weaning $E$. coli problems in intensive pig production. Proceedings of the $8^{\text {th }}$ "In-between" Symposium of the International Society for Animal Hygiene. Hungarian Veterinary Journal, 10:766-768.

CREECH, B.L., SPEARS, J.W., FLOWERS, W.L., HILL, G.M., LLOYD, K.E., ARMSTRONG, T.A. \& ENGLE, T.E. 2004. Effect of dietary trace mineral concentration and source (inorganic vs. chelated) on performance, mineral status, and fecal mineral excretion in pigs from weaning through finishing. Journal of Animal Sciences, 82:2140-2147.

GENGELBACH, G.P., WARD, J.D. \& SPEARS, J.W. 1994. Effect of dietary copper, iron and molybdenum on growth and copper status of beef cows and calves. Journal of Animal Sciences, 72:2722-2727.

GOODWIN, R. \& BURROUGHS, S. (Eds) 1995. Genetic evaluation terminal line program results. Des Moines, lowa: National Pork Producers Council. 
JONGBLOED, A.W. \& LENIS, N.P. 1993. Excretion of nitrogen and some minerals by livestock, in Nitrogen flow in pig production and environmental consequences, edited by M.W.A. Verstegen L.A. den Hartog \& G.J.M. van Kempen. Wageningen, The Netherlands: Pudoc Scientific.

KLASING, K.C. 2001. Protecting animal health and well being: nutrition and immune function, in Scientific advantages in animal nutrition: Promise for the new century, edited by National Research Council. Washington DC: National Academy Press.

MAHONEY, J.P., BUSH, J.A., GUBLER, C.J., MORETZ, W.H., CARTWRIGHT, G.E. \& WINTROBE, M.M. 1955. Studies on copper metabolism. Excretion of copper by animals. Journal of Laboratory and Clinical Medicine, 46:702-708.

NATIONAL RESEARCH COUNCIL 1998. Nutrient requirements of swine, $10^{\text {th }} \mathrm{ed}$. Washington DC: National Academic Press.

PABOEUF, F., NYS, Y. \& CORLOUËR, A. 2000. Réduction des rejets en cuivre et en zinc chez le porc charcutier par le diminutation de la supplémentation minérale. Journées de la Recherche Porcine en France, 32:59-66.

PULS, R. 1994. Mineral levels in animal health, $2^{\text {nd }}$ ed. Clearbrook, British Columbia, Canada: Sherpa International.

UNDERWOOD, E.J. 1977. Trace elements in human and animal nutrition. New York: Academic Press.

VAN HEUGTEN, E., O'QUINN, P.R., FUNDERBURKE, D.W., FLOWERS, W.L. \& SPEARS, J.W. 2004. Growth performance, carcass characteristics, plasma minerals, and fecal mineral excretion in grower-finisher swine diets with levels of trace minerals lower than common in industry levels. Journal of Swine Health and Production, 12:237-241.

WEIGAND, E. \& KIRCHGESSNER, M. 1980. Total true efficiency of zinc utilisation. Determination and homeostasis dependence upon the zinc supply status in young rats. Journal of Nutrition, 110:469-480. 